\title{
Characterization of bhatooru, a traditional fermented food of Himachal Pradesh: microbiological and biochemical aspects
}

\author{
Savitri $\cdot$ T. C. Bhalla
}

Received: 10 July 2012/Accepted: 4 September 2012/Published online: 18 September 2012

(C) The Author(s) 2012. This article is published with open access at Springerlink.com

\begin{abstract}
A number of traditional fermented products are prepared and consumed in Himachal and the types of traditional fermented products of Himachal are unique and different from other areas. Bhatooru is an indigenous leavened bread or roti and constitutes the staple diet of rural population of Himachal. The microbiological analysis of the inoculums (malera) revealed that it composed of a consortium of microorganisms. Population of Lactobacillus, Leuconostoc and Saccharomyces cerevisiae increased from 4.77 to $8.0 \log \mathrm{cfu} / \mathrm{g}$ of dry matter in $10 \mathrm{~h}$ of fermentation. The amount of total proteins increased from 13.6 to $18.4 \%(\mathrm{w} / \mathrm{w})$. The total sugars during fermentation decreased from 74.1 to $50.1 \%$ (w/w) on dry weight basis. However, the reducing sugar level of the fermenting samples increased significantly from 7.8 to $16.5 \mathrm{mg} / \mathrm{g}$ dry matter in the first $4 \mathrm{~h}$ and thereafter, it gradually decreased to $10.0 \mathrm{mg} / \mathrm{g}$ dry matter. Similarly starch content decreased from 70.2 to $48.3 \%$ (w/w) on dry weight basis by $10 \mathrm{~h}$ of fermentation. In fermented samples protease activity increased from $0.48 \mathrm{U} / \mathrm{g}$ dry matter to $11.5 \mathrm{U} / \mathrm{g}$ in $6 \mathrm{~h}$ and then decreased to $3.21 \mathrm{U} / \mathrm{g}$ on dry weight basis at $10 \mathrm{~h}$. Amylase activity initially increased from 65.0 to $79.4 \mathrm{U}$ to $6 \mathrm{~h}$ and then declined to $69.9 \mathrm{U} / \mathrm{g}$ of dry matter. Fermentation in bhatooru significantly enhanced the B vitamin levels especially thiamine, riboflavin and nicotinic acid and essential amino acids viz methionine, phenylalanine, threonine, lysine and leucine.
\end{abstract}

Keywords Bhatooru . Traditional fermented foods . Himachal Pradesh · Fermentation

Savitri · T. C. Bhalla $(\bowtie)$

Department of Biotechnology, Himachal Pradesh University, Summerhill, Shimla 171005, Himachal Pradesh, India e-mail: bhallatc@rediffmail.com

\section{Introduction}

Fermentation is one of the oldest methods of food preservation and is widely practiced at household level by rural folk to produce variety of traditional fermented foods and beverages (Cooke et al. 1987; Sasson 1988). Fermented foods generally preserve pleasant flavor, aroma, texture, enhanced nutritive values and good keeping quality under ambient conditions (Law et al. 2011). Several indigenous fermented foods and beverages produced at the household level in Swaziland were reviewed by Masarirambi et al. (2009). India being a large country displays climatic, ethnic and religious diversities vis-à-vis variation in food production and consumption. A lot of diversity prevails in the food habits of the people living in different parts of the country especially in the hilly regions where people have evolved indigenous method of preparing fermented foods and beverages based on easily available local raw materials. The skills of food preservation existed in the native people and the know-how of these fermentation was propagated orally (Prajapati 2003). Diversity of fermented foods in Asia is directly related to food culture of each and every community, and also the availability of raw materials (Tamang 2011).

In Himachal Pradesh, people have developed traditional food processing technologies for preparing fermented foods from locally available substrates largely governed by the ethnic preference, agroclimatic conditions, socio-cultural ethos and religion. A number of traditional fermented products are prepared and consumed in Himachal and the types of traditional fermented products of Himachal are unique and different from other areas (Thakur et al. 2003). Bhatooru, chilra, seera, siddu, gulgule, marchu, sepubari and pickles made from various locally available fruits and vegetables and different beverages like kinnauri, chhang, 
sura, behmi, etc. are some indigenous fermented products of Himachal Pradesh (Savitri 2007). Fermented foods have been a part of the staple diet in the rural areas of Himachal (specially the districts of Lahaul and Spiti, Kinnaur, Chamba and Kullu).

Bhatooru is indigenous leavened bread that contributes the staple diet of rural population of Himachal. Bhatooru is served with vegetables, dal or curry for routine meals and deep-fried on festive occasions. Malera is a traditional inoculum used for preparation of bhatooru.

\section{Materials and methods}

The samples of the inoculum (malera) used for bhatooru fermentation were collected aseptically from different areas of the state, stored in refrigerator and used for further studies. Wheat flour for preparation of bhatooru was purchased from the local market of Shimla, Himachal Pradesh ('Shakti Bhog brand').

\section{Preparation of bhatooru}

Bhatooru was prepared by mixing $450 \mathrm{~g}$ of wheat flour with $300 \mathrm{ml}$ of water. $50 \mathrm{~g}$ of malera (traditional inoculum) was added to the mixture and knead to form consistent dough. The dough was kept at $25^{\circ} \mathrm{C}$ in incubator for $10 \mathrm{~h}$ for fermentation. After every $2 \mathrm{~h}$, samples were taken and stored at $4{ }^{\circ} \mathrm{C}$ for further analysis. For microbiological analysis, the samples were processed immediately. A part of the dough was baked to prepare bhatooru.

Microbial profile during the fermentation

One gram of malera and one gram of dough sample withdrawn at an interval of $2 \mathrm{~h}$ were plated on nutrient agar, Czapek Malt agar and Lactobacillus selection agar plates for isolation of bacteria, yeasts and lactic acid bacteria by incubating at $30^{\circ} \mathrm{C}$ for bacteria and $25^{\circ} \mathrm{C}$ for yeasts. The number of colonies of bacteria and yeasts that appeared on plates after 24-48 h of incubation were counted and expressed as $\mathrm{cfu} \mathrm{g}^{-1}$ of the sample. The microorganisms isolated were identified at and submitted to Microbial Type Culture Collection and Gene Bank (MTCC), Chandigarh.

Biochemical analysis

Samples during bhatooru dough fermentation were analyzed for various biochemical parameters viz., moisture by Winton and Winton (2001), total acidity by Amerine et al. (1980) and $\mathrm{pH}$. Total proteins were estimated by using the methods of Lowry et al. (1951) and total carbohydrates were estimated by phenol sulphuric acid method (Dubois et al. 1956). Reducing sugars were estimated by DNSA method given by Miller (1959). Starch was estimated according to Hedge and Hofreiter (1962). The activity of protease and amylase was assayed by the method given by Manachini et al. (1988) and Bernfield (1955), respectively. SDS polyacrylamide gel electrophoresis of the proteins of fermented dough has also been performed to analyze the protein profile (gliadin and glutenin) during bhatooru fermentation.

Vitamin and amino acid analysis

Analysis of vitamins in fermented dough, malera and flour has been done according to Šnajdrová et al. (2004). For assay of water soluble B vitamins, the samples of fermented food were filtered through $0.45 \mu \mathrm{m}$ pore size filters. The mobile phase composed of acetonitrile:HPLC water (75:25) and $0.1 \%$ orthophosphoric acid. Samples $(5 \mu \mathrm{l})$ of the solution of water-soluble vitamins were injected into the HPLC column. Identification of compounds was made by comparing their retention times and UV spectra with those of standards. The vitamin concentrations in the samples were calculated from the integrated areas of the samples and their corresponding standards.

For amino acid analysis, sample was first hydrolysed (Schilling et al. 1996) and then derivatization (Hûsek 1991) was done. Prior to analysis, the samples were dried at room temperature for $40 \mathrm{~h}$. One gram sample was taken and transferred to glass sample tubes. These samples were placed inside a glass hydrolysis chamber. To each tube, $2 \mu \mathrm{l}$ of norleucine was added as internal standard solution (1,500 ppm in $0.1 \mathrm{M} \mathrm{HCl})$. A $200 \mu \mathrm{l}$ of $6 \mathrm{M} \mathrm{HCl}$ was introduced to the bottom of the chamber and kept at $105{ }^{\circ} \mathrm{C}$ in an oven for $24 \mathrm{~h}$ to fully hydrolyze the samples. After complete hydrolysis, the remaining traces of acid were removed by washing with $15 \mu \mathrm{l}$ of water and then dried at $50{ }^{\circ} \mathrm{C}$. The hydrolysate was dissolved in $120 \mu \mathrm{l}$ of $25 \mathrm{mM}$ $\mathrm{HCl}$.

An aliquot of the hydrolysate was taken in a vial which usually contained less than $100 \mu \mathrm{g}$ of amino acids. To this $100 \mu \mathrm{l}$ of water:ethanol:pyridine (60:32:8) was added and mixed properly. Then $5 \mu$ of ECF was added to this mixture and the tube was shaken gently for about $5 \mathrm{~s}$ till foaming due to gas evolution occurred. $100 \mu \mathrm{l}$ of chloroform (containing $1 \% \mathrm{ECF}$ ) was added and the vials were gently tapped to facilitate separation of the two layers. $2 \mu \mathrm{l}$ of chloroform layer (lower layer) was injected in GC. Gas chromatographic analysis was carried out on a Netel Chromatograph GC (MICHRO-9100) equipped with Chromosorb WHP $15 \%$ SE-30 column coupled with flow Ionization Detector. The GC was operated at the oven temperature $170-295^{\circ} \mathrm{C}$, injector temperature 
170-280 ${ }^{\circ} \mathrm{C}$, ramp rate $5^{\circ} \mathrm{C}$ and carrier flow (nitrogen) $5 \mathrm{ml} / \mathrm{min}$.

\section{Results and discussion}

Microbiological analysis of malera (traditional inoculum) and dough in bhatooru fermentation

The microbiological analysis of malera revealed that it was a consortium of microorganisms which mainly consisted of lactic acid bacteria and yeast. Lactobacillus plantarum (MTCC 8296), Leuconostoc sp. and Saccharomyces cerevisiae (MTCC 7840) were isolated from different samples of malera. The microflora of malera depends on flour, water used for dough preparation, utensils used, prevailing hygienic conditions as well as various parameters of the fermentation. The most relevant bacteria isolated from sourdough belonged to the genus Lactobacillus (Stolz 2003). Various yeast strains have also been isolated from spontaneous sourdough fermentations such as Saccharomyces cerevisiae and Pichia satoi (Beech and Davenport 1971). There have been several reports (Okada et al. 1992; Oura et al. 1982; Spicher 1984; Spicher and Schroder 1978, 1980) of lactobacilli occurring among the dominant microbial population in sourdough where they contribute to dough fermentation. Lactobacillus species are widely distributed in various fermented foods, dairy products and plant and animal materials (Cai et al. 1999).

A large number of bacteria and yeast were isolated from fermented dough samples of bhatooru fermentation at different intervals of time (Table 1). The microflora of the fermented dough was mainly dominated by yeast (Saccharomyces cerevisisae), lactic acid bacteria (Lactobacillus plantarum) and Bacillus sp. The gas producing Leuconostoc sp. also appeared at $4 \mathrm{~h}$ of fermentation causing leavening of dough. The source of these organisms might be the ingredients, vessels, and the surroundings followed by rapid multiplication during fermentation. With the progress in fermentation, total microbial count increased from $6 \times 10^{4}$ to $1 \times 10^{8} \mathrm{cfu} / \mathrm{g}$ decreasing the $\mathrm{pH}$ from 5.94 to 4.18. The decrease in the $\mathrm{pH}$ prevents the growth of undesirable microorganisms but the desirable microorganisms like yeast, Leuconostoc and Lactobacilli can very well propagate at this $\mathrm{pH}$. Saccharomyces cerevisisae has been reported from various fermented foods and beverages such as bhalle, beer, burukutu, bourbon whiskey, coffee beans, cider, merissa, fufu, tape, ogi, puto, dosa, idli, papdam, kecap, lao chao, warri, scotch whiskey, etc. (Padmaja and George 1999; Batra and Millner 1974, 1976; Soni and Sandhu 1990). Some species of Bacillus and other bacteria such as Kocuria rhizophila, Pseudomonas synxantha and Microbacteriun saperdae were also found during the initial stages of bhatooru fermentation and these organisms gradually disappeared with the progress of fermentation. This may be due to the production of acids and gas from various carbohydrates by lactic acid bacteria thus making the environment unfit for many of the bacterial population initially present.

Dough used for bhatooru preparation has also been prepared without the addition of malera (control) to compare the fermentation process with malera added preparation. These studies showed the involvement of only bacteria like Bacillus sp., Kocuria rhizophila and Enterobacter sp. in control and the total count of bacterial population increases from $4 \times 10^{2} \mathrm{cfu} / \mathrm{g}$ at $0 \mathrm{~h}$ to $5 \times 10^{6} \mathrm{cfu} /$ $\mathrm{g}$ of dry matter at 10th h. Microorganisms (Leuconostoc sp., Lactobacillus sp. and S. cerevisiae) which actively produce gases and acids were absent in the control dough (Table 1). Moreover, such preparation lacked the typical aroma otherwise contributed by the yeast and lactic acid bacteria in the fermented product.

Chemical and biochemical analysis of fermented dough

The traditional inoculum-malera used for bhatooru fermentation was collected from Kullu and analyzed for various biochemical parameters. The biochemical analysis of malera revealed that it is an acidic dough having a $\mathrm{pH}$ of 3.7, titratable acidity of 0.62 and $46 \%$ moisture. It has $20 \%$ (w/w) protein, $571.0 \mathrm{mg} / \mathrm{g}$ of dry matter carbohydrate, $496.0 \mathrm{mg} / \mathrm{g}$ dry matter starch and $23.2 \mathrm{mg} / \mathrm{g}$ dry matter reducing sugars. The activities of amylase and protease were 25.7 and $1.67 \mathrm{U} / g$ respectively.

With the decrease in $\mathrm{pH}$ from 5.94 to 4.18 , total acidity in fermented sample increased from 0.028 to $0.14 \%$. This may be due to the production of acetic acid and lactic acid during fermentation by lactic acid bacteria and yeast. The increase in acid content is in proportion with the increase in lactic acid bacteria count. The increase in the total acidity in fermented sample helps in enhancing the shelf life of fermented foods as well as it imparts typical aroma and taste to the product (Hammes and Gänzle 1998). However, the change in both $\mathrm{pH}$ (from 6.7 to 6.48) and acidity (from 0.018 to $0.045 \%$ ) is very less in the case of control. The fall in $\mathrm{pH}$ and increase in titratable acidity in dough during fermentation are considered important for prevention of malfermentation and spoilage of bread. At low $\mathrm{pH}$ of sourdough, the growth and activity of spoilage organisms such as Bacillus subtilis or Clostridia which cause ropiness, are suppressed (Hammes and Gänzle 1998).

The change in total protein content during bhatooru fermentation has been studied and it was found that there was an increase in total proteins from 13.6 to $18.4 \%$ (w/w) on dry weight basis from 0 to 10 th $\mathrm{h}$ of fermentation. However, there was no significant change in total protein 
Table 1 Changes in microflora, pH and volume in dough during bhatooru fermentation

\begin{tabular}{|c|c|c|c|}
\hline $\begin{array}{l}\text { Incubation } \\
\text { time }(h)\end{array}$ & Volume (ml) & $\begin{array}{l}\text { Total count } \\
(\log \mathrm{cfu} / \mathrm{g})\end{array}$ & Predominant microorganism \\
\hline 0 & 500 & 4.77 & Saccharomyces cerevisiae, Bacillus sp., Lactobacillus plantarum, Kocuria rhizophila \\
\hline 2 & 510 & 6.69 & $\begin{array}{l}\text { S. cerevisiae, Bacillus sp., Microbacterium saperdae, L. plantarum, Kocuria rhizophila, } \\
\text { Pseudomonas synxantha }\end{array}$ \\
\hline 4 & 539 & 6.69 & S. cerevisiae, Bacillus sp., L. plantarum, Leuconostoc sp. \\
\hline 6 & 560 & 7.0 & S. cerevisiae, Bacillus sp., L. plantarum, Leuconostoc sp. \\
\hline 8 & 583 & 7.56 & S. cerevisiae, L. plantarum, Leuconostoc sp. \\
\hline 10 & 597 & 8.0 & S. cerevisiae, L. plantarum \\
\hline
\end{tabular}

Bacillus cereus, Flavobacterium sp. and Cellolomonas sp. were reported during initial stages of fermentation as minor microbial flora

content in case of control. Increase in protein content in fermented food on dry weight basis might be due to utilization of carbohydrates. The amount of total sugars during fermentation decreased from $74.1-50.1 \%(\mathrm{w} / \mathrm{w})$ on dry weight basis in fermented dough and 73.9-66.1\% (w/w) on dry weight basis in control dough (Table 2). The decrease in total sugars might be due to the metabolism of sugars by bacteria and yeast. The sugars are rapidly metabolized to acids, ethanol, biomass, carbon dioxide and other metabolites required for the growth of microorganisms with concomitant decrease in total sugars during fermentation (Mensah 1997).

As given in Table 2 the level of reducing sugar in dough increased significantly in the first $4 \mathrm{~h}$ of fermentation and thereafter it gradually decreased to $10.0 \mathrm{mg} / \mathrm{g}$ dry matter by $10 \mathrm{~h}$. In control, the level of reducing sugars increased gradually from 4.0 to $21.1 \mathrm{mg} / \mathrm{g}$ dry matter up to $8 \mathrm{~h}$ and thereafter it declined to $15.7 \mathrm{mg} / \mathrm{g}$ dry matter at 10th $\mathrm{h}$. Initial increase in reducing sugar can be implicated with the activity of inherent amylases in the flour which might have got activated with the addition of water during the preparation of dough. The rate of conversion of starch to reducing sugars mediated by amylases was initially higher than the rate of consumption of reducing sugars by the fermentative organisms and later the rate of sugar consumption got enhanced due to augmentation in the number of fermentative organisms. It has been reported that as the $\mathrm{pH}$ of the ferment decreases, the saccharification of starch by amylases and amyloglucosidases is also reduced and this results in gradual decrease of reducing sugars concentration towards the later stages of fermentation (Syu and Chen 1997; Narendranathan et al. 1997).

The change in starch content in dough during $10 \mathrm{~h}$ of bhatooru fermentation is given in Table 2. The starch content in dough was $70.2 \%(\mathrm{w} / \mathrm{w})$ on dry weight basis at $0 \mathrm{~h}$. After $2 \mathrm{~h}$ of fermentation it started decreasing and finally (at $10 \mathrm{~h}$ fermentation) its level went down to $48.3 \%$ (w/w) on dry weight basis. The starch content in control almost remained constant. Starch is saccharified to monosaccharides and disaccharides by inherent amylases of flour, which are utilized by lactic acid bacteria and yeast present in the sourdough for their growth and production of acids (Röcken et al. 1992).

Protease and amylase activity

The protease activity was more in fermented dough sample as compared to that of control. In control, the activity of enzyme ranged from 0.32 to $0.50 \mathrm{U} / \mathrm{g}$ dry weight of sample while in fermented dough samples, the protease activity increased from $0.48 \mathrm{U} / \mathrm{g}$ dry matter to $11.5 \mathrm{U} / \mathrm{g}$ in $6 \mathrm{~h}$ and then decreased to $3.21 \mathrm{U} / \mathrm{g}$ on dry weight basis in $10 \mathrm{~h}$ of fermentation (Table 2). The proteolytic activity during the fermentation of sourdough leads to the enhancement of free amino acid content that are well known precursors of flavour formation in bread (Thiele et al. 2002). The proteolysis is caused by flour enzymes, microbial enzymes of flour and by sourdough bacteria. The proteolytic activity has been mainly attributed to the endogenous enzymes of the flour (Kratochvil and Holas 1988; Spicher and Nierle 1988). The lactic acid bacteria of sourdough have also been reported to produce protease during the fermentation of sourdough (Spicher and Nierle 1988).

It has also been observed that the electrophoretic profiles of the fermented dough are different from that of unfermented or flour samples. During bhatooru fermentation, wheat proteins (gliadins and glutenins) had got hydrolysed due to proteolytic activity of flour and microorganisms (Fig. 1, 2). The disappearance of protein (especially glutenins subunits) bands in the fermented dough were observed, which may be due to the hydrolysis of both HMW (high molecular weight) and LMW (low molecular weight) gluten subunits and $\alpha, \beta, \gamma$ and $\omega$ subunits of gliadins during fermentation by the activity of proteolytic enzymes. The hydrolysis of wheat proteins with the progress of fermentation can be correlated to the increase in amino acid level in the fermented dough. The substantial hydrolysis of gliadin and glutenin proteins occur during sourdough fermentation due to $\mathrm{pH}$-mediated activation of cereal enzymes, especially aspartic proteinase that appears 


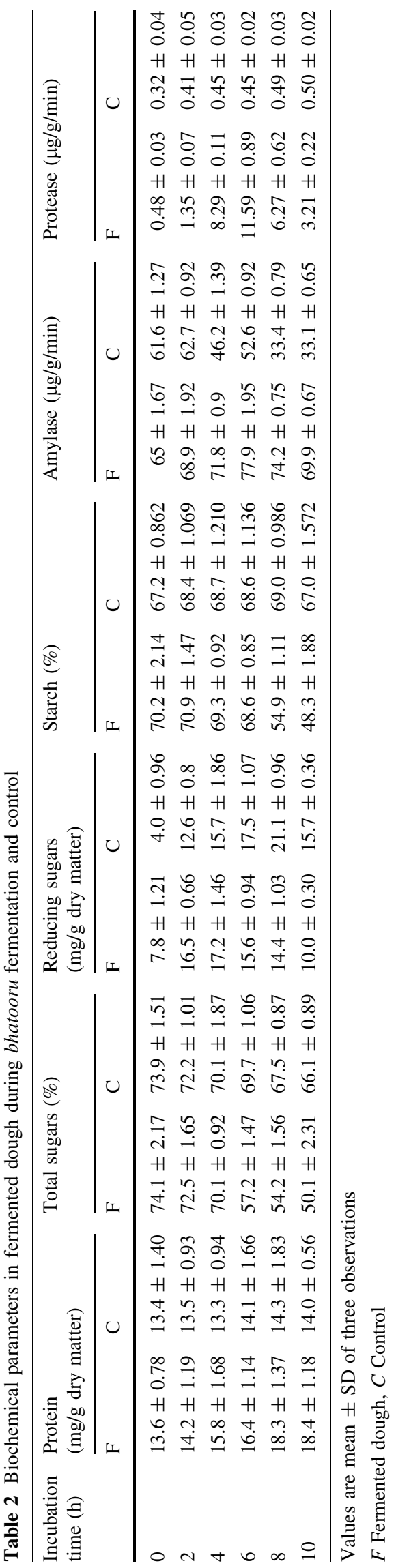

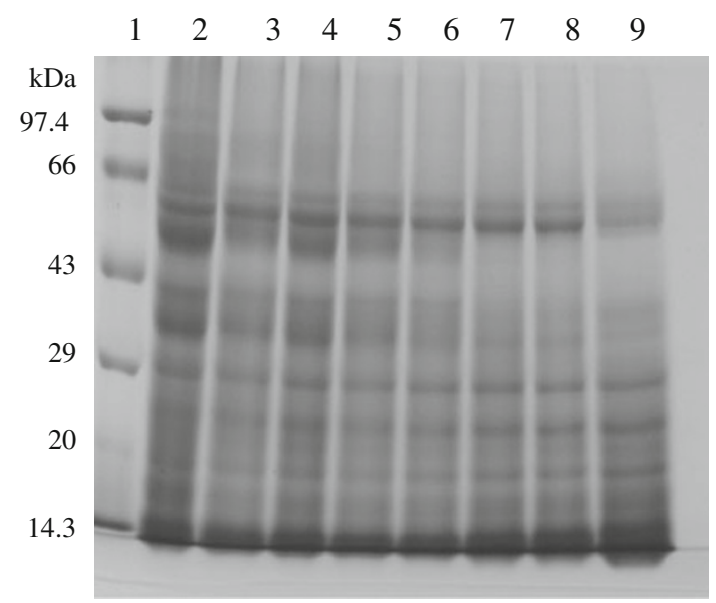

Fig. 1 SDS-PAGE of wheat proteins (gliadins) of dough. Lane 1: Molecular weight markers (phosphorylase b $97.4 \mathrm{kDa}$, bovine serum albumin $66 \mathrm{kDa}$, ovalbumin $43 \mathrm{kDa}$, carbonic anhydrase $29 \mathrm{kDa}$, soybean trypsin inhibitor $20 \mathrm{kDa}$, lysozyme $14.3 \mathrm{kDa}$ ). Lane 2: Flour sample. Lane 3-8: Fermentation samples taken at different time intervals $(2-10$ h). Lane 9: Malera sample

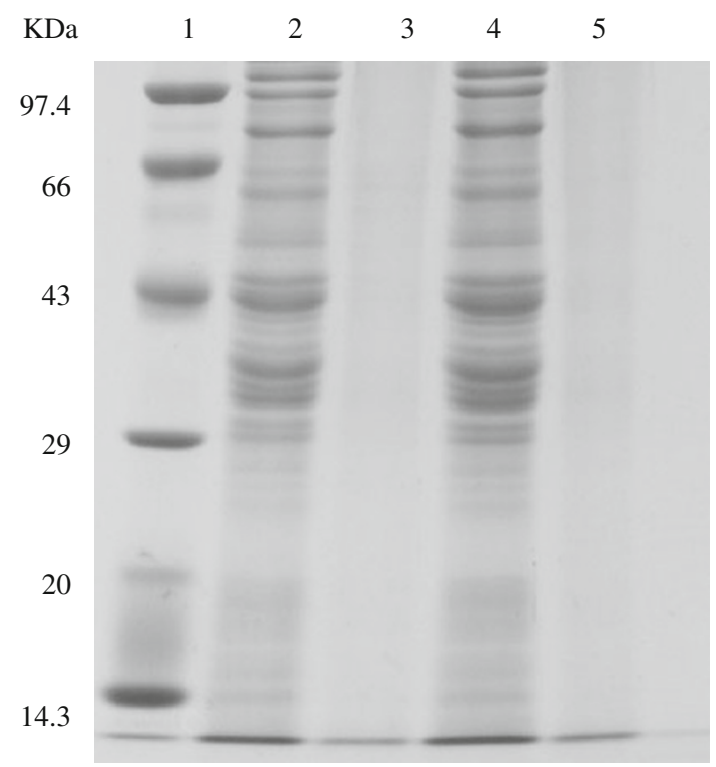

Fig. 2 SDS-PAGE of wheat proteins (glutenins) of dough. Lane 1: Molecular weight markers (phosphorylase b $97.4 \mathrm{kDa}$, bovine serum albumin $66 \mathrm{kDa}$, ovalbumin $43 \mathrm{kDa}$, carbonic anhydrase $29 \mathrm{kDa}$, soybean trypsin inhibitor $20 \mathrm{kDa}$, lysozyme $14.3 \mathrm{kDa}$ ). Lane 2 and 4 : Glutenin samples extracted from different flour samples. Lane 3 and 5: Glutenin samples extracted from $10 \mathrm{~h}$ of fermented dough during bhatooru fermentation

to be active in the conditions of wheat sourdough (Thiele et al. 2003; Loponen et al. 2004). Furthermore, sourdough fermentation results in solubilisation and depolymerization of the gluten macropolymer (Thiele et al. 2004).

The amylolytic activity was measured up to $10 \mathrm{~h}$ of fermentation in dough and control samples and the results are given in Table 2. It first increased from 65.0 to $79.4 \mathrm{U} / \mathrm{g}$ of dry matter in $6 \mathrm{~h}$ and then decreased to $69.9 \mathrm{U} / \mathrm{g}$ of dry 
Table 3 Vitamin and amino acid content in wheat flour, malera and fermented dough

\begin{tabular}{llcc}
\hline & Flour & Malera & $\begin{array}{l}\text { Fermented } \\
\text { dough }\end{array}$ \\
\hline $\begin{array}{l}\text { Vitamins }(\mathrm{mg} / \mathrm{g}) \\
\quad\end{array}$ & & & \\
$\begin{array}{c}\text { Thiamine } \\
\quad \text { per } 100 \mathrm{~g})\end{array}$ & $0.52 \pm 0.026$ & $2.7 \pm 0.26$ & $1.57 \pm 0.07$ \\
Riboflavin & $0.003 \pm 0.00017$ & $0.005 \pm 0.0003$ & $0.081 \pm 0.002$ \\
Nicotinic acid & $0.051 \pm 0.0045$ & $0.97 \pm 0.02$ & $0.65 \pm 0.02$ \\
Cyanocobalamin & $0.006 \pm 0.0002$ & $0.008 \pm 0.0002$ & $0.057 \pm 0.003$ \\
Amino acid $(\mathrm{mg} / \mathrm{g})$ & & & \\
Methionine & $2.6 \pm 0.26$ & $5.80 .3 \pm 0.1$ & $5.7 \pm 0.06$ \\
Phenylalanine & $2.8 \pm 0.2$ & $6.6 \pm 0.3$ & $6.0 \pm 0.08$ \\
Threonine & $1.6 \pm 0.1$ & $4.6 \pm 0.17$ & $4.7 \pm 0.07$ \\
Lysine & $1.2 \pm 0.2$ & $3.2 \pm 0.26$ & $2.3 \pm 0.2$ \\
Leucine & $4.9 \pm 0.17$ & $5.6 \pm 0.26$ & $5.5 \pm 0.2$ \\
\hline
\end{tabular}

Values are mean \pm SD of three observations

matter by $10 \mathrm{~h}$ of fermentation. Amylase activity was lower i.e. 33.1 units/g in case of control. Increase in amylolytic enzymes during the course of fermentation has been reported in several Indian fermented foods such as Punjabi warri, idli, dosa, jalebi, khaman (Soni and Arora 2000, 1990; Sankaran 1998).

Vitamin and amino acid analysis

The fermentation of dough significantly enhanced the B vitamin levels especially thiamine, riboflavin and nicotinic acid (Table 3). The rise in the level of various vitamins especially thiamine and riboflavin appears to be due to the increase the microflora and yeasts, most of which have the ability to produce vitamins from simple precursors (Steinkraus 1998). Soni and Arora (2000) also reported significant increase in the water-soluble B vitamins including thiamine, riboflavin and cyanocobalamin in bhalle fermentation and dosa batter fermentation. Warri fermentation also brings about an appreciable rise in water-soluble $\mathrm{B}$ vitamins including thiamine, riboflavin and cyanocobalamin (Soni and Arora 2000).

It was observed that fermentation significantly modified the relative amount of amino acids in dough. The various essential amino acids such as methionine, phenylalanine, threonine, leucine and lysine exhibited remarkable increase (Table 3). However, control did not show an appreciable increase in amino acid content with respect to the wheat flour. The increase in these amino acids in bhatooru fermentation is an indication of hydrolysis of proteins by the activities of proteolytic enzymes as well as the addition of such amino acids by the fermentative microbes, due to their metabolic activities in the product. Similar findings were reported by Soni and Arora (2000) during the warri, idli and dosa fermentation where they observed a significant
Table 4 Comparative analysis of bhatooru and roti (chapati)

\begin{tabular}{lll}
\hline Parameters & Bhatooru & Roti \\
\hline $\mathrm{pH}$ & $6.00 \pm 0.03$ & $7.06 \pm 0.06$ \\
Total acidity (\%) & $0.024 \pm 0.003$ & - \\
Proteins (\%) & $6.2 \pm 0.02$ & $5.1 \pm 0.17$ \\
Total sugars (\%) & $62.8 \pm 0.83$ & $66.2 \pm 1.2$ \\
Reducing sugars (mg/g) & $11.0 \pm 0.36$ & $13.0 \pm 1.2$ \\
Starch (\%) & $47.2 \pm 1.3$ & $65.0 \pm 1.7$ \\
Amylase (U/g) & $0.180 \pm 0.005$ & $\mathrm{ND}$ \\
Protease (U/g) & $\mathrm{ND}$ & $\mathrm{ND}$ \\
Thiamine $(\mathrm{mg} / 100 \mathrm{~g})$ & $1.3 \pm 0.03$ & $0.49 \pm 0.02$ \\
Riboflavin $(\mathrm{mg} / \mathrm{g})$ & $0.041 \pm 0.002$ & $0.001 \pm 0.0001$ \\
Nicotinic acid $(\mathrm{mg} / \mathrm{g})$ & $0.021 \pm 0.002$ & $0.011 \pm 0.0017$ \\
Cyanocobalamin $(\mathrm{mg} / \mathrm{g})$ & $0.029 \pm 0.003$ & $0.002 \pm 0.0002$ \\
Methionine $(\mathrm{mg} / \mathrm{g})$ & $1.4 \pm 0.03$ & $1.1 \pm 0.036$ \\
Threonine $(\mathrm{mg} / \mathrm{g})$ & $1.4 \pm 0.02$ & $1.0 \pm 0.07$ \\
Phenylalanine $(\mathrm{mg} / \mathrm{g})$ & $2.1 \pm 0.3$ & $1.5 \pm 0.026$ \\
Lysine $(\mathrm{mg} / \mathrm{g})$ & $0.72 \pm 0.04$ & $0.56 \pm 0.036$ \\
\hline
\end{tabular}

Values are mean \pm SD of three observations

increase in free amino acids from 9.79-45.15 mg, $8.3-12.9 \mathrm{mg}$ and $10.2-17.8 \mathrm{mg}$ respectively on dry weight basis. The increase in free D- and L-amino acids in sourdoughs by various lactic acid bacteria and yeasts has been reported by Gobbetti et al. (1994).

The final products bhatooru and chapati/roti prepared from fermented and unfermented dough were analyzed for various biochemical parameters and results are summarized in Table 4. From these studies it can be concluded that nutritive value (especially vitamins and amino acids) in bhatooru which was prepared by fermentation with the addition of traditional inoculum (malera), is greatly enhanced as compared to chapati/roti.

\section{Conclusions}

From these studies it is evident that traditional fermentation adds quality to staple food bhatooru by way of enhancing their protein content, vitamin and essential amino acids. This is the first ever study on bhatooru, a traditional fermented food of rural hilly people of $\mathrm{Hi}$ machal which shows that it has better nutritional value as compared to chapatti/roti prepared from unfermented dough. So the use of this fermented food as a source of protein, vitamins and amino acids can be popularized to improve the nutrition and social well-being of rural and urban people of Himachal Pradesh. In addition to this, these studies will provide base for scale up of processes practiced at household level to small-scale industrial units by the entrepreneurs. 
Acknowledgments The author (Savitri) gratefully acknowledges Council of Scientific and Industrial Research (CSIR), New Delhi, India for financial support in the form of Junior Research Fellowship and Senior Research Fellowship.

Open Access This article is distributed under the terms of the Creative Commons Attribution License which permits any use, distribution, and reproduction in any medium, provided the original author(s) and the source are credited.

\section{References}

Amerine MA, Berg HW, Kunkee RE, Ough ES, Singleton VL, Webb AD (1980) The Technology of wine making, 4th edn. AVI Publishing Co Inc, Westport, pp 77-243

Batra LR, Millner PD (1974) Some Asian fermented foods and beverages and associated fungi. Mycol 66:942-950

Batra LR, Millner PD (1976) Asian fermented foods and beverages. Dev Ind Microbiol 17:117-128

Beech F, Davenport R (1971) Isolation, purification and maintenance of yeasts. Methods Microbiol 4:153-182

Bernfield P (1955) Amylases, $\alpha$ and $\beta$. In: Colowick S, Kaplan NO (eds) Methods Enzymol. Academic Press, New York, pp 149-158

Cai Y, Okada H, Mori H, Benno Y, Nakase T (1999) Lactobacillus paralimentarius sp. nov. isolated from sourdough. Int $\mathrm{J}$ Sys Bacteriol 49:1451-1455

Cooke RD, Twiddy DR, Reilly PJA (1987) Lactic acid fermentation as a low-cost means of food preservation in tropical countries. FEMS Microbiol Rev 46:1196-1200

Dubois M, Gilles KA, Hamilton JK, Rebers PA, Smith F (1956) Colorimetric methods for determination of sugar and related substances. Anal Chem 28:350-356

Gobbetti M, Corsetti A, Rossi J (1994) The sourdough microflora. Interaction between lactic acid bacteria and yeasts: metabolism of amino acids. J Microbiol Biotechnol 10:275-279

Hammes WP, Gänzle MG (1998) Sourdough bread and related products. In: Wood BJB (ed) Microbiology of fermented foods, vol I, 2nd edn. Blackie Academic and Professional, London, pp 199-216

Hedge JE, Hofreiter BT (1962) Methods of estimating starch and carbohydrates. In: Whistler RL, Miller JNB (eds) Carbohydrate chemistry, vol 17. Academic Press, New York, pp 163-201

Hûsek P (1991) Amino acid derivatization and analysis in five minutes. FEBS Lett 280:354-356

Kratochvil J, Holas J (1988) Use of a cereal protein substrate for characterization of proteolytic enzymes in rye sourdough. Getreide Mehl und Brot 42:166-169

Law SV, Bakar AF, Hashim MD, Hamid AA (2011) Popular fermented foods and beverages in Southeast Asia. Int Food Res J $18: 475-484$

Loponen J, Mikola M, Katina K, SontG-Strohm T, Salovaara H (2004) Degradation of HMW glutenins during wheat sourdough fermentations. Cereal Chem 81:87-90

Lowry OH, Rosenbrough NJ, Farr AL, Randall RJ (1951) Protein measurement with folin phenol reagent. J Biol Chem 193:256

Manachini PL, Fortina MG, Parinic C (1988) Thermostable alkaline protease produced by Bacillus thermoruber-a new species of Bacillus. Appl Microbiol Biotechnol 28:409-413

Masarirambi MT, Mhazo N, Dlamini AM, Mutukumira AN (2009) Common indigenous fermented foods and beverages produced in Swazialnd—a review. J Food Sci Technol 46(6):505-508
Mensah P (1997) Fermentation- the key food safety assurance in Africa? Food Cont 8:271-278

Miller GL (1959) Use of dinitrosalicyclic acid reagent for the determination of reducing sugars. Anal Chem 31:426-428

Narendranathan N, Hynes SH, Thomas C, Ingledew WM (1997) Effect of Lactobacilli on yeast-catalyzed ethanol fermentation. Appl Environ Microbiol 63:4158-4163

Okada S, Ishikawa M, Yoshida I, Uchimura T, Ohara N, Kozaki M (1992) Identification and characteristics of lactic acid bacteria isolated from sourdough sponges. Biosci Biotechnol Biochem 56:572-575

Oura H, Suomalainen H, Viskari R (1982) Bread making. In: Rose $\mathrm{AH}$ (ed) Economic microbiology, fermented food, vol 7. Academic Press, London, pp 88-146

Padmaja G, George M (1999) Oriental fermented foods; biotechnological approaches. In: Marwaha SS, Arora JK (eds) Food processing: biotechnological applications. Asiatech Publishers Inc, New Delhi, pp 143-189

Prajapati JB (2003) Fermented foods of India. In: Proceedings of International seminar and workshop on social well being, Anand, India, 13-14 November 2003, pp 1-4

Röcken N, Rick M, Reinkemeier M (1992) Controlled production of acetic acid in wheat sourdoughs. Lebensm Unters Forsch 191:206-209

Sankaran R (1998) Fermented foods of Indian subcontinent. In: Wood BJB (ed) Microbiology of fermented foods, vol II, 2nd edn. Blackie academic and Professional, London, pp 753-789

Sasson A (1988) Biotechnologies and developing countries: challenges and promises. The Courier 112:97-100

Savitri, Bhalla TC (2007) Traditional foods and beverages of Himachal Pradesh. Ind J Trad Knowl 6:17-24

Schilling MR, Khanjian HP, Souza LAC (1996) Gas chromatographic analysis of amino acids as ethyl chloroformate derivatives. J Am Inst Conser 35:45-59

Šnajdrová R, Kristová-Mylerová V, Crestia D et al (2004) Nitrbiotransformation by Aspergillus niger. J Mol Catal B Enzym $29: 227-232$

Soni SK, Arora JK (2000) Indian fermented foods: biotechnological approaches. In: Marwaha SS, Arora JK (eds) Food processing: biotechnological applications, 1st edn. Asiatech Publishers Inc, New Delhi, pp 143-190

Soni SK, Sandhu DK (1990) Indian fermented foods: microbiological and biochemical aspects. Indian J Microbiol 30:135-157

Spicher G (1984) The microflora of sourdough. XVII Communication: bacterial composition of commercial sourdough starters. Z Lebensm Unters Forsch 178:106-109

Spicher G, Nierle W (1988) Proteolytic activity of sourdough bacteria. Appl Microbiol Biotechnol 28:487-492

Spicher G, Schroder R (1978) The microflora of sourdough IV. The species of rod shaped lactic acid bacteria of the genus Lactobacillus occurring in sourdoughs. Z Lebensm-UntersForsch 167:342-354

Spicher G, Schroder R (1980) The microflora of sourdough. IX Communication: comparative investigation over the performance of lactic acid bacteria (Genus Lactobacillus Beijerinck) occurring in starter cultures (Reinzuchtsauer). Z Lebensm Unters Forsch 170:262-266

Steinkraus KH (1998) Bioenrichment: production of vitamins in fermented foods. In: Wood BJB (ed) Microbiology of fermented foods, vol II, 2nd edn. Blackie Academic \& Professional, London, pp 602-621

Stolz P (2003) Biological fundamentals of yeast and Lactobacilli fermentation in bread dough. In: Kulp K, Lorenz K (eds) Handbook of dough fermentations. Marcel Dekker Inc, New York, pp 23-43 
Syu MJ, Chen YH (1997) A study on the $\alpha$-amylase fermentation performed by Bacillus amyloliquefaciens. Chem Eng J 65:237-247

Tamang JP (2011) Prospects of Asian fermented foods in global markets. The 12th Asian Food Conference 2011. BITEC, Bangna, Bangkok, Thailand, 16-18 June 2011

Thakur N, Kumar D, Savitri, Bhalla TC (2003) Traditional fermented foods and beverages of Himachal Pradesh. Inven Intel 173-178

Thiele C, Gänzle G, Vogel RF (2002) Contribution of sourdough lactobacilli, yeast and cereal enzymes to the generation of amino acids in dough relevant for bread flavour. Cereal Chem 79:45-51
Thiele C, Gänzle G, Vogel RF (2003) Fluorescence labeling of wheat proteins for determination of gluten hydrolysis and depolymerization during dough processing and sourdough fermentation. J Agric Food Chem 51:2745-2752

Thiele C, Grasssi S, Gänzle G (2004) Gluten hydrolysis and depolymerization during sourdough fermentation. J Agric Food Chem 51:45-51

Winton AL, Winton KB (2001) General chemical group: Constituent groups a) Water. In: Winton AL, Winton KB (eds) Techniques of food analysis, Agrobios (India), Jodhpur, pp 55-59 